\title{
Istota eklezjologii pierwszego tysiąclecia w ujęciu prawosławnym i rzymskokatolickim w świetle dokumentu: „Synodalność i prymat w pierwszym Tysiącleciu: Ku wspólnemu rozumieniu w służbie jedności Kościoła”, Chieti 2016
}

\author{
ks. Andrzej Kuźma \\ Wydział Teologiczny, Chrześcijańska Akademia Teologiczna w Warszawie \\ Polska \\ ORCID: 0000-0003-4485-9821 \\ a.kuzma@chat.edu.pl
}

\begin{abstract}
rev. A. Kuźma, The essence of the ecclesiology of the first millennium in the Orthodox and Roman Catholic perspective in light of: SYNODALITY AND PRIMACY DURING THE FIRST MILLENNIUM: TOWARDS A COMMON UNDERSTADING IN SERVICE TO THE UNITY OF THE CHURCH, Chieti 2016, Elpis, 21 2019: 109-120.

Abstract: This article consists of two parts. The first part presents the achievements of the Catholic-Orthodox dialogue which commenced in 1982. The second part contains a Polish translation of a document which was adopted at the 14th plenary session of the Catholic-Orthodox dialogue in Chieti in 2016. The first phase of the dialogue, which took place between 1982-2000, raised issues which are in essence common for both the Orthodox Church and Roman Catholic Church and in many aspects convergent. Starting in 2006, the Commission addressed the relations of synodality and primacy in the Church. The Chieti Document addresses the question of understanding primacy in the first millennium of the undivided Church. As the authors of this document point out, the history of this period should serve as a benchmark in the quest for Church unity in the future.
\end{abstract}

\begin{abstract}
Streszczenie: Artykuł składa się z dwóch części. W pierwszej przedstawione zostały rezultaty osiagnięć dialogu katolicko-prawosławnego, który rozpoczął się w 1982 r. Drugą część stanowi tłumaczenie na j. polski dokumentu, który został przyjęty na 14-tej sesji plenarnej dialogu katolicko-prawosławnego w Chieti w 2016 r. Pierwsza faza dialogu, która przebiegała w latach 1982-2000 poruszała zagadnienia, które w swojej istocie zarówno dla Kościoła prawosławnego jak też dla Kościoła rzymskokatolickiego są wspólne i w wielu punktach zbieżne. Począwszy od 2006 r. Komisja zajęła się tematem zależności synodalności i prymatu w Kościele. Dokument z Chieti porusza zagadnienie rozumienia prymatu w pierwszym tysiącleciu niepodzielonego Kościoła. Historia tego okresu, jak wskazują autorzy dokumentu powinna stanowić punkt odniesienia względem szukania dróg jedności Kościoła w przyszłości.
\end{abstract}

Keywords: Catholic-Orthodox dialogue, ecumenism, Chieti Document, synodality and primacy in the Church

Słowa kluczowe: dialog katolicko-prawosławny, ekumenizm, dokument z Chieti, synodalność i prymat w Kościele

Każdy dialog jest procesem dynamicznym. Dialog teologiczny między Kościołem rzymskokatolickim i prawosławnym, który rozpoczął się w 1980 r. posiada już swoją historię i znaczące osiągnięcia. Będąc procesem dynamicznym, również ten dialog potrzebuje ciągłej aktualizacji, badania jego osiągnięć i wskazywania na wciąż istniejące problemy. Historia dialogu prawosławno-rzymskokatolickiego jak też jego rezultaty w znaczącym stopniu zostały opracowane i opisane w literaturze polskojęzycznej (Por. Hryniewicz, 1993; Bujak, 2016; Glaeser, 2000; Kuźma, 2014a, 16: s. 11-18). Ostatnim dokumentem, który jest rezultatem pracy Międzynarodowej Komisji Mieszanej dialogu między Kościołem rzymskokatolickim i Kościołem prawosławnym jest dokument którego tytuł brzmi: Synodalność i prymat w pierwszym Tysiącleciu: Ku wspólnemu rozumieniu w stużbie jedności Kościoła. Dokument ten został przyjęty przez Komisję w 2016 r. w czasie XIV sesji tego dialogu w Chieti we Włoszech. Tekst tego dokumentu w thumaczeniu na j. polski stanowi integralną część niniejszego opracowania.

\section{Osiągnięcia dialogu}

Dialog teologiczny między Kościołem prawosławnym i rzymskokatolickim mógł zaistnieć dzięki szeregu inicjatywom zarówno ze strony Kościoła rzymskokatolickiego, jak też ze strony Kościoła prawosławnego. Wyraźne ocieplenie stosunków pomiędzy Kościołami nastąpiło po II Wojnie Światowej i związane było z jednej strony ze wstąpieniem na tron patriarchów Konstantynopola Atenagorasa I w 1948r., z drugiej zaś bardzo ważnym okazało się zajęcie katedry rzymskiej najpierw przez Jana XXIII (19581963) następnie Pawła VI (1963-1978). Szereg działań, które zostały podjęte przez wspomnianych hierarchów określane są mianem „Dialogu miłości” (Glaeser, 2018, 
s. 94-97). Okazały się one podstawą do rozwoju dalszych działań, które przywiodły do zainicjowania i rozpoczęcia dialogu teologicznego na poziomie międzynarodowym pomiędzy Kościołem rzymskokatolickim i prawosławnym. Z perspektywy czasu trwający dialog można podzielić na dwie fazy. Pierwsza trwająca w latach 1980- 2000 i druga 2005- do okresu obecnego (Kuźma, 2014a, s.12)․․

\section{Rezultaty pierwszej fazy dialogu}

Tematy, którymi zajęła się Komisja Mieszana w pierwszej fazie dialogu nie stanowiły zagadnień kontrowersyjnych, lecz podkreślały bliskość doktryny i wspólne pojmowanie szeregu teologicznych kwestii. Pierwszym dokumentem, który został opracowany i przyjęty na drugiej sesji plenarnej w Monachium w 1982 r. przez Komisję był tekst: Misterium Kościoła i Eucharystii w świetle tajemnicy Trójcy Świętej (Hryniewicz 1993, s. 35-44). Autorzy dokumentu odwoływali się do niezwykle ważnych czynników wspólnej tradycji, mianowicie Trójcy Świętej, jako objawienia Bożego jak też Kościoła i Eucharystii określając je jako misterium. Związek Kościoła i Eucharystii jest nierozerwalnym: „Kościół pielgrzymujący celebruje Eucharystię na ziemi aż do czasu, gdy jego Pan przyjdzie przekazać Królestwo Bogu Ojcu, aby Bóg był wszystkim we wszystkich” (I,4c). Dokument podkreśla również zależność celebracji eucharystycznej w Kościele lokalnym odziaływującej na cały Kościół powszechny. Kolejnym dokumentem przyjętym prze Komisję był tekst zatwierdzony na IV sesji plenarnej w Bari w 1987 r. zatytułowany: Wiara, sakramenty i jedność Kościoła (Hryniewicz, 1993, s. 45-55). Również ten dokument podkreślał wiele elementów wspólnego nauczania. Wiara postrzegana jest przede wszystkim jako dar Boży, który nie jest czynnikiem statycznym, lecz dynamicznym. Dar wiary potrzebuje dobrowolnej odpowiedzi człowieka: „Dana przez Boga wiara, która głosi Kościól, jest przepowiadana i przekazywana w widzialnym Kościele lokalnym (...). Człowiek jest włączony w Ciało Chrystusa przez swą wspólnotę (koinonija)w tym Kościele widzialnym, który przez życie sakramentalne i słowo Boże zasila w nim tę wiarę, przez którą działa w nim Duch Święty" (I,8). Istotnym punktem, który wpłynął na trudności w opracowaniu i przyjęciu omawianego dokumentu była praktykowana kolejność sakramentów inicjacyjnych w obu Kościołach. W tradycji prawosławnej kolejność ta wygląda następująco: Chrzest, Bierzmowanie, Eucharystia. W tradycji zaś Kościoła rzymskokatolickiego dwa ostatnie sakramenty posiadają kolejność odwróconą: Chrzest, Eucharystia, Bierzmowanie. Przy czym wszystkie trzy sakramenty oddzielone są od siebie znaczącym przedziałem czasowym. Taka prawidłowość dla strony prawosławnej

Taki podział jest umownym i uwzględnia pewną grupę dokumentów, która została przyjęta przez Mieszaną Komisję w tym okresie. Można również przyjać i z pewnością uzasadnić trzy fazy omawianego dialogu 1. 1980-1990, 2. 1990-2005, 3. 2005- do chwili obecnej. (Glaeser, 2018, s. 98). wydawała się nie do przyjęcia. Pomocnym i przekonywującym okazały się dla strony prawosławnej orzeczenia, które zostały wyrażone w okresie soborów focjańskich (879880 ) i przywołane w procesie opracowywania dokumentu mówiące o dopuszczalnej rozbieżności praktyk w różnych Kościołach lokalnych ${ }^{2}$. Z drugiej jednak strony delegaci Kościoła rzymskokatolickiego stwierdzali, że kolejność, która zachowywana jest w Kościele prawosławnym jest prawidłowa, natomiast kolejność sprawowania sakramentów w Kościele rzymskokatolickim wynika ze względów pastoralnych i posiada już swoją dawność (II,50).

Kolejnym dokumentem, który został przyjęty przez Komisję mieszaną był tekst o dość długim tytule: Sakrament kapłaństwa w sakramentalnej strukturze Kościoła ze szczególnym uwzględnieniem znaczenia sukcesji apostolskiej dla uświęcenia i jedności Ludu Bożego (Hryniewicz, 1993, s. 56-66) który został przyjęty na V Sesji plenarnej dialogu obradującej w Nowym Valamo w Finlandii w czerwcu 1988r. Niewielka rozpiętość czasowa, która dzieliła spotkania Komisji mieszanej w przyjęciu dwóch ważnych dokumentów nie wynikała z tego, że podkomisje i Komitet koordynacyjny intensywnie pracowały przez okres jednego roku. Dokument o kapłaństwie przygotowywany był niemalże równolegle $\mathrm{z}$ dokumentem o sakramentach. W wyniku pojawienia się trudności w sprecyzowaniu wyrażeń w dokumencie o sakramentach, który był przyjęty w końcu w Bari w 1987 r., dokument o kapłaństwie otrzymał pewne opóźnienie $\mathrm{w}$ jego plenarnej analizie i przyjęciu. Treść przyjętego tekstu podkreślała wspólną tradycję sukcesji apostolskiej, która jest niezwykle ważna w Kościele rzymskokatolickim jak też prawosławnym. Sukcesja apostolska stanowi źródło dla wszelkiej posługi, która została ustanowiona w Kościele: „Posługiwanie Dwunastu daje świadectwo, jako historycznych świadków tego, czego Pan dokonał, jest jedyne i nie powtarzalne. Położyli oni fundament raz na zawsze i nikt na przyszłość nie będzie mógł budować, inaczej niż na fundamencie tak położonym" (p.20). To z posługi apostolskiej wycieka posługa biskupa, prezbitra i diakona. Eucharystia sprawowana pod przewodnictwem biskupa i przy współudziale pozostałych nie wykluczając tych którzy stanowią Lud Boży na którym spoczywa Królewskie kapłaństwo: „W celebracji Eucharystii całe zgromadzenie - każdy według swojej godności jest <liturgiem> wspólnoty; jest nim jedynie przez Ducha" (p.24). Autorzy dokumentu stwierdzają również, że do posługi kapłańskiej „wyświęca się jedynie mężczyzn” (p.32).

W toczącym się dialogu nabrzmiewał pewien problem, który zajmował umysły przede wszystkim prawosławnej strony Komisji mieszanej a dotyczył prozelityzmu i odradzającego się uniatyzmu. Pierwsze znaczące przesłani wskazujące na skierowanie uwagi na ten problem pojawiły się w czasie IV sesji plenarnej w Bari w 1987 r. Na kolejnym spotkaniu plenarnym w Nowym Valamo w 1988 r. powoła-

,Każda stolica otrzymała od tradycji pewne stare zwyczaje. Na ich temat nie powinno się zawzięcie dyskutować, ani kłócić. Kościół rzymski zachowuje właściwe sobie zwyczaje i dobrze, że tak czyni. Z drugiej strony Kościół Konstantynopolitański także zachowuje pewne zwyczaje sobie właściwe (...)”, (Mansi XVII,489, za Hryniewicz 1993, s. 158). 
no specjalną dwustronną podkomisję, której zadaniem było zajęcie się problemem uniatyzmu. O tego momentu właściwie problemy natury eklezjologicznej stały się dominujące w trwającym dialogu. Wynikiem ustaleń dwustronnej podkomisji było określenie tematu na kolejne etapy dialogu. Proponowany temat brzmiał: Eklezjologiczne i kanoniczne konsekwencje sakramentalnej natury Kościoła. Soborowość (synodalność) i autorytet $w$ Kościele. Proponując taki temat można zauważyć, że Komisja mieszana w wyraźny sposób skierowano tok dalszych rozmów ku zagadnieniom soborowości i prymatu w Kościele. Odpowiednie podkomisje zajęły się przygotowaniem projektu dokumentu na sesję plenarną, lecz jak się okazało prace nad dokumentem z różnych przyczyn zostały odłożone na wiele lat.

Kolejna sesja plenarna tj. VI, która odbyła się we Freising k. Monachium w dniach 7-15 czerwca 1990 zwołana została by zająć się dokumentem o soborowości i prymacie, lecz w rzeczywistości zdominowana była przez kwestie związane $\mathrm{z}$ uniatymem i prozelityzmem. Wiele Kościołów prawosławnych nie przysłało delegatów na to spotkanie, natomiast skład delegacji Kościoła rzymskokatolickiego był niemalże kompletnym (Hryniewicz, 1993, s. 243). Po kilku dniach dyskusji Komisja zdołała przyjąć pewne uzgodnienia nawiązujące do zagadnienia uniatyzmu jako nieprawidłowej i błędnej drogi w poszukiwaniu jedności. W dokumencie z Freising stwierdzano: „(...) odrzucamy < uniatyzm> jako metodę poszukiwania jedności, ponieważ jest on przeciwny wspólnej tradycji naszych Kościołów. Tam gdzie uniatyzm był stosowany jako metoda, nie osiągnął swojego celu, którym było zbliżenie Kościołów, lecz spowodował nowe podziały" (6 b-c)(Hryniewicz, 1993, s. 67-69). Takie sformułowanie należy stwierdzić w zupełnie nowym świetle pokazywało postawę Kościoła rzymskokatolickiego wobec problemu jedności Kościoła, jednak problemu nie rozwiązywały.

Aktywność Kościoła greko-katolickiego dalej rozwijała się zwłaszcza na terenie Ukrainy i Rumunii. Niektórzy prawosławni hierarchowie nawoływali do przerwania dialogu. Najbardziej chyba wyraźnym głosem był apel patriarchy Rumunii Teoktysta skierowany do uczestników VI Sesji plenarnej dialogu we Freising w 1990 r., później zaś wypowiedzi metropolity smoleńskiego Cyryla (Gundiajewa), o zawieszenie lub przerwanie dialogu (Kuźma, 2014a, 16, s. 16-17). Dialog jednak trwał nadal i kolejne sesje, które się odbyły, VII plenarna w Balamand w Libanie (1724 czerwca 1993 r. ) jak też VIII w Baltimor w USA (9-19 lipca 2000 r.) dalej zajmowały się bolącą kwestią uniatyzmu. Szczególnie ważnym osiągnięciem w tym zakresie był przyjęty przez wspólną Komisję dokument w Balamand, który został zatytułowany: Uniatyzm, metoda unijna przeszłości a obecne poszukiwania petnej wspólnoty (Hryniewicz, 1994, s. 77-82). Autorzy dokumentu powtarzali myśl, która była wyrażona w dokumencie z Freising (1990), dotyczącą tego, że uniatyzm nie może być stosowany jako metoda przywrócenia jedności w Kościele. Dokument z Balamand jest jednak bardziej kompletny i porusza więcej zagadnień, które odnoszą się do problemu. Należałoby również nadmienić, że omawiany dokument został się obiektem krytyki przez niektóre Kościoły prawosławne $^{3}$ jak też pewne środowiska rzymskokatolickie, ale też został pozytywnie przyjęty przez synod patriarchatu Konstantynopola, Antiochii i Rumunii (Hryniewicz, 2004, s. 317). Spotkanie w Baltimor, którego gospodarzem był kardynał William Keeler, wieloletni członek Komisji nie przyniosło przełomu w rozwiązaniu kryzysu związanego z odrodzeniem się uniatyzmu. Problemy, które zaistniały na Ukrainie tuż przed 2000 r. związane z odbieraniem świątyń prawosławnym przez grekokatolików jeszcze bardziej zaostrzały istniejący konflikt.

Pomimo tego, że nie było decyzji o formalnym zawieszeniu dialogu, podjętej przez Komisję mieszaną, to należałoby uważać, że tak właśnie się stało- dialog został zawieszony.

\section{Druga faza dialogu}

Biorąc pod uwagę zaistniałe okoliczności należy przypuszczać, że wraz z wstąpieniem na tron Papieży rzymskich Benedykta XVI, strona prawosławna uznała za stosowne aby odnowić dialog z Kościołem rzymskokatolickim (Bujak, 2016, s. 17). Patriarcha ekumeniczny Bartolomeusz zaprosił w dniach 11-13 września 2005 r. przedstawicieli wszystkich lokalnych autokefalicznych Kościołów prawosławnych do Konstantynopola stawiając pytanie o możliwość i gotowość ponownego rozpoczęcia dialogu z Kościołem rzymskokatolickim. Odpowiedź wszystkich delegacji była jednoznaczna i pozytywna (Kuźma, 2005, s. 11). W związku z rezygnacją z powodów zdrowotnych arcybiskupa Stylianosa z Australii z funkcji współprzewodniczącego Dialogu, uczestnicy zebrania na jego miejsce wybrali metropolite Pergamonu Jana (Ziziulasa). Została również wyrażona propozycja aby kolejne spotkanie Komisji plenarnej odbyło się w Serbii.

Zaplanowana IX sesja plenarna odbyła się w dniach 18-23 września 2006 r. w Belgradzie na zaproszenie serbskiego Kościoła Prawosławnego. Komisja mieszana zajęła się dokumentem, który od kilkunastu lat oczekiwał na swoje opracowanie i przyjęcie. Był to dokument dotyczący autorytetu i soborowości w Kościele, wstępnie opracowany w 1990 r. w Moskwie pt. Konsekwencje eklezjologiczne i kanoniczne sakramentalnej natury Kościoła. Wspólnota kościelna, soborowość $i$ autorytet. Dokument poruszał zagadnienie autorytetu w Kościele i prymatu, którego wyrażenia oczekiwała zdaje się najbardziej strona prawosławna. Zebranie w Belgradzie nie zakończyło się sukcesem w postaci dokumentu końcowego, ale znacząco zbliżyło obie strony i to nie tylko w kontekście teologicznym ale również w kontekście czysto ludzkim. Po nakreśleniu punktów spornych dalsze prace $\mathrm{w}$ celu poprawienia dokumentu powierzono komisji redakcyjnej, która spotkała się w marcu 2007 r. w Rzymie (Bouwen, 2010, s. 277-289).

\footnotetext{
Kościół grecki odrzucił dokument, natomiast Kościół rosyjski odniósł się do niego z pewną rezerwą (Hryniewicz, 2004, s. 317).
} 
Kolejne spotkanie Mieszanej Komisji Dialogu Międzynarodowego należy zaliczyć do bardziej udanych. Dziesiąta sesja plenarna odbyła się w dniach 8-15 października 2007 r. w Rawennie ${ }^{4}$. Rezultatem tego spotkania było podpisanie wspólnego dokumentu: Konsekwencje eklezjologiczne $i$ kanoniczne sakramentalnej natury Kościoła. Wspólnota kościelna, soborowość $i$ autorytet (Kuźma, 2008 (219), s. 10-13; 2008 (220), s. 11-13). Dokument ten stał się istotnym wkładem w prowadzony dialog i jak się później okaże będzie swego rodzaju natchnieniem dla kolejnego dokumentu, który zostanie opracowany przez Komisję mieszaną. Dokument z Rawenny składa się ze wstępu (par. 1-4) dwóch części głównych (par. 5-16 i 17-44) i zakończenia (par. 45).We wstępie uczestnicy spotkania w Rawennie wskazują na potrzebę dialogu we współczesnych czasach. Następnie szkicują drogę dotychczasowego dialogu miedzy Kościołem rzymskokatolickim i prawosławnym. W pierwszej części głównej, która nosi tytuł Podstawy soborowości $i$ autorytetu, autorzy starają się wyjaśnić na czym polega soborowość w życiu Kościoła. Odpowiedzialność za wiarę nie spoczywa wyłącznie na biskupach jako nosicielach posługi apostolskiej, lecz każdy ochrzczony w imię św. Trójcy jest za nią odpowiedzialny. Wymiar soborowy powinien być obecny na wszystkich trzech poziomach życia kościelnego, lokalnym, regionalnym i powszechnym. W Kościele posługa zbudowana jest na autorytecie. Sprawowanie autorytetu oparte zaś jest na miłości. Druga główna część (17-44) nosi tytuł Potrójna aktualizacja soborowości i autorytetu. Jest to chyba centralna część dokumentu poddająca analizie znaczenie prymatu i soborowości na trzech poziomach. Na poziomie lokalnym, prymat ten przynależy do biskupa i sprawowany jest we wspólnocie z kapłanami i wiernymi. Na poziomie regionalnym autorzy dokumentu zwracają uwagę na formowanie się lokalnych Kościołów w większe jednostki administracyjne, gdzie pierwszy (protos) biskup danego regionu nie powinien niczego czynić bez konsultacji z pozostałymi. Pozostali biskupi również nie powinni czynić co się tyczy ogółu bez porozumienia z pierwszym biskupem. Na poziomie powszechnym uczestnicy sesji w Rawennie wskazują na istnienie w starożytności pięciu głównych Kościołów (Rzym, Konstantynopol, Aleksandria, Antiochia, Jerozolima), które w sposób soborowy podejmowały decyzje. Pierwsze miejsce w tym porządku (taxis) należało do Kościoła rzymskiego. W zakończeniu zwraca się uwagę na potrzebę pogłębienia rozumienia roli biskupa „pierwszego Kościoła” w łonie wspólnoty wszystkich Kościołów. Dlatego też w Rawennie została podjęta decyzja, że kolejnym tematem, którym zajmie się Komisja Mieszana będzie: Rola biskupa Rzymu we wspólnocie Kościoła w pierwszym tysiacleciu.

\footnotetext{
4 W pracach nad przyjęciem dokumentu w Rawennie nie brali udziału przedstawiciele Patriarchatu moskiewskiego. Powodem opuszczenia spotkania prze delegację moskiewską była obecność w Komisji przedstawicieli autonomicznego Kościoła w Estonii, który został przyznany jako autonomiczny przez Patriarchat Konstantynopola w 1996r. nieuznawany był natomiast przez Patriarchat moskiewski.
}

\section{Droga do wypracowania dokumentu w Chieti}

Temat, który został podjęty jako kolejne zadanie dla wypowiedzenia się i opracowania przez Międzynarodową Komisję Mieszaną dialogu prawosławno-katolickiego Rola biskupa Rzymu we wspólnocie Kościoła w pierwszym tysiącleciu okazał się trudnym i w rezultacie uległ znaczącej modyfikacji. Pierwsze plenarne spotkanie Komisji mieszanej poświęcone temu tematowi odbyło się w dniach 16-23 października 2009 r. w Pafos na Cyprze (Bujak, 2016, s. 67-85; Kuźma 2009, s. 13). Komisja swoją pracę oparła na roboczym dokumencie wypracowanym przez Komitet Koordynacyjny na spotkaniu roboczym w dniach 27.09-04.10.2008 r. w Elunda na Krecie. Robocza wersja dokumentu dotykała zasadniczych kwestii rozumienia roli biskupa Rzymu we wspólnocie całego Kościoła i w jaki sposób to pierwszeństw było rozumiane i akceptowane w innych wielkich lokalnych Kościołach. W tej wersji dokumentu ${ }^{5}$ wskazywano na ogólny autorytet Kościoła rzymskiego i jego rolę jako pierwszego (protos), w ogólnie przyjętym porządku (taksis) lokalnych Kościołów. Autorytet ten wypływał z różnych czynników, najważniejszymi z nich był autorytet założenia przez apostołów Piotra i Pawła, oraz obecność ich grobów w tym mieście. W wypracowanym roboczym tekście znalazło się szereg historycznych opisów zdarzeń zarówno patrystycznych jak i kanonicznych, które przyczyniały się do wzrostu autorytetu i roli biskupa Kościoła w Rzymie. Dokument nie został jednak przyjęty. Zgodnie postanowiono, że jego treść będzie obiektem dyskusji na kolejnym spotkaniu Komisji Mieszanej.

XII sesja Międzynarodowej Komisji Mieszanej dialogu katolicko-prawosławnego przebiegała w Wiedniu w dniach 20-27 września 2010 r. Była ona kontynuacją prac, które rozpoczęte zostały na poprzednim spotkaniu w Pafos. Jednak i tutaj dokument ten nie otrzymał aprobaty i nie został poprawiony i przyjęty przez Komisję. Wydaje się, że szczególnie strona prawosławna wyrażała obiekcje co do wartości tego dokumentu, wskazując na zbyt historyczny charakter tekstu i znacząco przychylający się ku rozumieniu rzymskokatolickiemu problematyki. Postanowiono, że temat ten zostanie odłożony na późniejszy okres trwającego dialogu, natomiast dla potrzeb bieżących należy opracować tekst, który będzie poruszał zagadnienie bardziej w kontekście teologicznym niż historycznym (Bujak, 2016, s. 91-92; Kuźma, 2010, 11, s. 11). Z tego też względu został powołany Komitet Koordynacyjny, którego zadaniem było opracowanie dokumentu bardziej teologicznego niż historycznego o znaczeniu i pierwszeństwie biskupa i Kościoła rzymskiego.

\footnotetext{
Wersje robocze dokumentu nie są upubliczniane. Jednak w tym przypadku doszło do naruszenia tych zasad i tekst roboczy bez zgody Komisji dostał się do środków masowego przekazu i został opublikowany we włoskiej prasie. Tekst został też przetłumaczony na j. polski (Bujak, 2016, s. 74-85).
} 
Komitet Koordynacyjna spotykała się trzykrotnie w Rethymno, Rzymie i Paryżu' ${ }^{6}$ Tak znacząca ilość spotkań Komitetu wskazuje na trudności jakie towarzyszyły opracowaniu dokumentu roboczego dla potrzeb Komisji mieszanej. Rezultatem tych spotkań okazał się tekst, który nosił tytuł: Synodalność i prymat. W ten sposób przygotowany tekst stał się roboczą bazą dla XIII sesji plenarnej Międzynarodowej Komisji Mieszanej dialogu rzymskokatolicko-prawosławnego. Spotkanie Komisji odbyło się na zaproszenie Patriarchatu jerozolimskiego i przebiegało w stolicy Jordanii Ammanie w dniach 15-23 września 2014 r. Sesja ta okazała się jednak nie udaną i dokument, który był tak pieczołowicie przygotowywany na trzech spotkaniach Komitetu Koordynacyjnego został odrzucony (Kuźma, 2014b, s. 8). Dość znaczące rozbieżności pojawiły się w pewnych kwestiach teologicznych u samych prawosławnych. Do najważniejszych należałoby zaliczyć trudności polegające na szukaniu analogii pomiędzy jednością w Trójcy Świętej z jednej strony, z drugiej zaś, jednością i prymatem w Kościele na wszystkich trzech poziomach. Analogia ta w szczególny sposób przejawiała się w poglądach współprzewodniczącego Komisji metropolity Pergamonu Jana (Ziziulasa) z Patriarchatu ekumenicznego. Wyjściem z dość trudnej sytuacji była propozycja przygotowania nowego tekstu, który w bardziej bezpośredni sposób odnosiłby się do dokumentu z Rawenny. Dlatego też uczestnicy sesji planarnej w Ammanie podjęli decyzję o ponownym powołaniu Komitetu Koordynacyjnego, który na nowo podejmie analizę zagadnienia synodalności i prymatu. Komitet Koordynacyjny złożony z czterech teologów katolickich i czterech prawosławnych spotkał się w Rzymie w dniach 25-26 czerwca 2015 r. aby wzbogacić i rozszerzyć, szkic tekstu, który powstał w Ammanie. Nowy wypracowany projekt nosił tytuł: Ku wspólnemu rozumieniu synodalności i prymatu w Kościele w pierwszym tysiacleciu Kościoła. Kolejnym etapem w powstawaniu tego tekstu było spotkanie Komitetu Koordynacyjnego, który przebiegał w Rzymie w dniach 15-18 września 2015 r. Wzięło w nim udział dziesięciu teologów rzymskokatolickich i ty leż samo prawosławnych. Spotkanie przebiegało pod współprzewodnictwem kardynała Kurta Kocha i metropolity Pergamonu Jana Ziziulasa (Bouwen, 2017, s. 97-11). Komitet po naniesieniu poprawek przyjął powyższy tekst z zamiarem przedłożenia go dla Komisji mieszanej, która miała się zebrać na swej XIV sesji plenarnej jesienią 2016r.

\section{Spotkanie w Chieti}

XIV Sesja Plenarna dialogu katolicko-prawosławnego odbyła się w dniach 16-21 września 2016 r. w miejscowości Francavilla al Mare niedaleko Pescara we Włoszech,

\footnotetext{
Spotkania były organizowane przemiennie przez stronę prawosławną i rzymskokatolicką. Pierwsze spotkanie odbyło się w Rethymno (Kreta) w dniach 13-17.06.2011, drugie w Rzymie w dniach 21-26.11.2011, trzecie zaś w Paryżu w dniach 19-23.11.2012r.
}

która należy do diecezji Chieti-Vasto ${ }^{7}$. Gospodarzem tej sesji był Kościół rzymskokatolicki, natomiast spotkanie organizował w swojej diecezji arcybiskup Bruno Forte, który jest też członkiem Komisji mieszanej. W spotkaniu wzięli udział przedstawiciele wszystkich lokalnych autokefalicznych Kościołów prawosławnych oprócz delegacji Patriarchatu bułgarskiego. Ze strony zaś rzymskokatolickiej zabrakło dwóch członków Komisji. Sesja przebiegała pod przewodnictwem dwóch współprzewodniczących. Ze strony Kościoła rzymskokatolickiego współprzewodniczącym był kardynał Kurt Koch, przewodniczący Rady papieskiej do spraw jedności chrześcijan, za strony Kościoła prawosławnego arcybiskup Telmesos Hiob (Getcha), który między innymi pełni funkcję stałego przedstawiciela Patriarchatu ekumenicznego przy Światowej Radzie Kościołów.

Zgodnie z przyjętym zwyczajem, zanim Komisja Mieszana spotka się na sesji plenarnej wcześniej mają miejsce oddzielne spotkania członków strony prawosławnej i rzymskokatolickiej. Celem takich spotkań jest wstępne ustosunkowanie się do przedłożonego tekstu i ogólna dyskusja. Tym razem jednak strona prawosławna oprócz wspomnianych zadań winna była wybrać współprzewodniczącego Komisji strony prawosławnej. W związku ze swoim stanem zdrowia dotychczasowy współprzewodniczący metropolita Pergamonu Jan (Ziziulas) zrezygnował z pełnionej funkcji. Na stanowisko to powoływany jest zawsze członek Komisji wywodzący się z Patriarchatu ekumenicznego. Dlatego też propozycja Patriarchy Konstantynopola wskazywała na nowego członka tej Komisji arcybiskupa Telmesos Hioba (Getcha). Po dyskusjach i konsultacjach arcybiskup Hiob został nowym współprzewodniczącym Komisji mieszanej zastępując na tym miejscu metropolitę Pergamonu Jana (Ziziulasa)

W części popołudniowej 16 września miała miejsce pierwsza sesja plenarna. Po oficjalnym powitaniu przez gospodarza spotkania arcybiskupa Bruno Forte i przedstawicieli władzy cywilnej, którzy przybyli na inauguracyjną sesję plenarną właśnie w tym celu rozpoczęła się praca nad przygotowanym tekstem roboczym.

Zgodnie ze zwyczajem członkowie obu delegacji uczestniczą w uroczystych nabożeństwach celebrowanych na początku sesji plenarnej. Pierwsze nabożeństwo było celebrowane przez delegację Kościoła rzymskokatolickiego pod przewodnictwem kardynała Kurta Kocha i odbyło się 17 września w sobotę wieczorem w Katedrze św. Justyna z Chieti. Dla członków delegacji prawosławnej były przygotowane specjalne miejsca $\mathrm{w}$ czasie odprawianej Mszy. Członkowie delegacji prawosławnej z kolei św. Liturgię odprawiali pod przewodnictwem arcybiskupa Hioba w niedzielę 18 września w sanktuarium w Manoppello, gdzie znajduje się jeden z obrazów Chrystusa „nie ręką ludzką uczyniony". Sanktuarium to jest miejscem licznych

Początkowo spotkanie było planowane na rok 2017, z tego względu, że na czerwiec 2016 r. był zaplanowany Wielki Sobór Kościoła Prawosławnego. Okazało się jednak, że dla prawosławnych nie stwarzało wielkich problemów zaangażowanie się w dwa znaczące wydarzenia mające przebieg w tym samym roku. 
pielgrzymek zarówno wyznawców prawosławia jak też rzymskich katolików.

W toku prac plenarnych Komisja Mieszana, punkt po punkcie analizowała roboczy tekst, przygotowany w Rzymie w czerwcu 2015 r. pt.: Ku wspólnemu rozumieniu synodalności i prymatu $w$ Kościele $w$ pierwszym tysiącleciu Kościoła. Tytuł dokumentu budził pewne wątpliwości wśród członków Komisji. Zwracano uwagę, że takie sformułowanie daje pewne wrażenie już istniejącego rozumienia teologicznego synodalności i prymatu. Ponadto takie sformułowanie tytułu, według członków Komisji wskazuje na niemalże historyczny kontekst omawianego tematu (Bouwen, 2017, s. 115). Dlatego też w końcowym etapie pracy nad dokumentem stwierdzono, że lepszym streszczeniem dokumentu będzie tytuł: Synodalność i prymat w pierwszym Tysiacleciu. Ku wspólnemu rozumieniu $w$ stużbie jedności Kościoła. Taki też tytuł ostatecznie otrzymał przygotowany dokument. Przyjete sformułowanie oddaje lepiej istotę problemu i wskazuje na pierwsze Tysiąclecie jako źródło natchnienia dla dążeń zjednoczenia podzielonych chrześcijan $\mathrm{w}$ trzecim Tysiącleciu.

W trakcie dyskusji członkowie Komisji starali się bardziej precyzyjnie wyjaśnić zależność między synodalnością i prymatem w kontekście trzech poziomów: lokalnego, regionalnego i powszechnego. Ponadto ważnym punktem w dyskusji było wskazanie na cel prowadzonego dialogu. Paragraf 7 przyjętego dokumentu mówi, że celem dialogu jest przywrócenie ,pełnej jedności”. Wersja robocza dokumentu mówiła o jedynie o „pojednaniu”». Strona rzymskokatolicka wskazywała, że w dokumencie nie należy używać terminu technicznego ,jurysdykcja” w odniesieniu do pierwszego Tysiąclecia. Takie wyrażenie w tym okresie nie występowało. W ten sposób opracowany i poprawiony dokument stał się obiektem ogólnej akceptacji w czasie sesji kończącej XIV zebranie Komisji mieszanej. Należy dodać, że swoje obiekcje w stosunku do pewnych sformułowań zawartych w tekście wyraziła delegacja Patriarchatu gruzińskiego. Dokument ogólnie został zaakceptowany lecz obiekcje te ujęto w Komunikacie końcowym, nie wskazując kontrowersyjnych sformułowań: „Delegacja Patriarchatu gruzińskiego wyraziła swój brak zgody wobec niektórych paragrafów dokumentu" (Communique,14-th Plenary Session, Chieti, Italy, 16-21 september 2016.

\section{Ogólna charakterystyka dokumentu}

Dokument z Chieti pt.: Synodalność i prymat w pierwszym Tysiacleciu: Ku wspólnemu rozumieniu w stużbie jedności Kościoła jest drugim dokumentem, który został przyjęty przez wspólną Komisję mieszaną dotyczącym szeroko

\footnotetext{
Wydaje się, że ważne znaczenia w kontekście celu dialogów teologicznych odegrał dokument Relacje Kościoła prawosławnego z pozostatym światem chrześcijańskim, który został przyjęty na Soborze Kościoła prawosławnego na Krecie w 2016 r. gdzie w § 12 czytamy: „podczas prowadzenia dialogów teologicznych wspólnym celem wszystkich jest ostateczne przywrócenie jedności w prawidłowej wierze i miłości”.
}

pojętego tematu synodalności i prymatu w Kościele. Już na pierwszy rzut oka dokument nieco odbiega od wcześniej przyjętych dokumentów przez Komisję na przestrzeni jej działalności. Różnica ta widoczna jest w szeregu przypisów zastosowanych w dokumencie. Przyczynę takiego stanu rzeczy można rozpatrywać z dwóch punktów widzenia: 1) Tematyka podejmowana $\mathrm{w}$ tekście jest na tyle trudna i niejednoznacznie interpretowana, że potrzebuje dodatkowego wyjaśnienia w postaci przypisów. 2) Autorzy dokumentu starają się wykazać, że wyrażenia zawarte w tekście znajdują swoje oparcie i ugruntowanie w tradycji patrystycznej i kanonicznej. Niemniej jednak dokument zredagowany w ten sposób staje się bardziej teologicznym traktatem akademickim niż tekstem przeznaczonym dla szerokiego gremium.

Dokument składa się z 21 paragrafów i podzielony jest na trzy zasadnicze części: 1) Wstęp (§1-7), 2) Część główna (§ 8-19) i 3) i Zakończenie (§20-21). Przy czym główna część stanowi zasadniczą treść dokumentu wyrażając i objaśniając zagadnienie synodalności i prymatu na trzech poziomach.

We wstępie dokumentu autorzy analizują istotę Kościoła i starają się wyjaśnić dlaczego zagadnienie synodalności i prymatu w pierwszym Tysiącleciu zasługuje na naszą uwagę. $\mathrm{W}$ pierwszych frazach tekstu zwracają uwagę na Boże ustanowienie Kościoła wynikające z woli Ojca i udziału w tym ustanowieniu pozostałych osób Trójcy Świętej. Kościół ustanowiony został jako jedność. Ta jedność Kościoła jako swoje źródło posiada wspólnotę panującą pomiędzy Osobami św. Trójcy. W ten sposób jedność pozostaje permanentnym zadaniem Kościoła. Kościół zawsze istniał z jednej strony jako lokalna wspólnota pod przewodnictwem biskupa $\mathrm{z}$ drugiej zaś jako wspólnota Kościołów lokalnych (§2). W tym kontekście niezwykle ważnym jest odczytanie zależności jaka panowała pomiędzy lokalnymi Kościołami i w jaki sposób wyrażała się ich jedność. W Kościele istnieje pewien porządek wynikający z ustanowienia Bożego. Ten porządek oparty jest na roli „pierwszego" (protos) w Kościele i jego relacji ze wspólnotą wyrażającą się w soborowości lub synodalności甲. „W Kościele prymat należy do jego Głowy- Jezusa Chrystusa" (§4), stwierdzają autorzy dokumentu. W życiu empirycznym Kościoła „tradycja chrześcijańska wyraźnie wskazuje, że w życiu soborowym Kościoła na różnych poziomach biskup był uznawany jako „pierwszy” (§4). Rozbieżne pojmowanie relacji pomiędzy soborowością i prymatem, uważają uczestnicy XIV sesji Komisji mieszanej „odegrało znaczącą rolę w podziale między prawosławnymi i katolikami” (§5). Dlatego też ważnym jest aby wspólnie zastanowić się nad tym zagadnieniem, które jest różnie interpretowane i jest właściwie źródłem podziału. Jako kryterium odniesienia tradycji autorzy dokumentu wskazują na pierwsze Tysiąclecie, kiedy chrześcijanie wschodu i zachodu stanowili jedność. W okresie

\footnotetext{
Greckie słowo synodos może być tłumaczone jest na j. polski zarówno jako synod jak i sobór. Dlatego też wyrażenia „synodalność” i „soborowość" należy rozumieć jako synonimy. Niemniej jednak w niniejszym opracowaniu zwykle stosowane jest wyrażenie „soborowość” jako bardziej ugruntowane w świadomości eklezjologicznej.
} 
pierwszych dziesięciu wieków istnienia chrześcijaństwa dochodziło do pewnych czasowych rozłamów, ale nigdy nie były one trwałe (§7). Podział, który zaistniał w XI w. okazał się trwałym i w kolejnych wiekach został pogłębiony. Interpretacja rozumienia prymatu i soborowości jak też odniesienie jej do pierwszego Tysiąclecia w tym kontekście jest niezwykle ważna i „może dać istotne wskazówki dla prawosławnych i katolików w ich wysiłkach na rzecz przywrócenia współcześnie pełnej jedności” (§7).

Główną część dokumentu stanowi jednak treść odnosząca się do rozumienia zagadnienia prymatu i soborowości na trzech poziomach życia Kościoła. Jak wcześniej było stwierdzone trzystopniowy podział, który stanowi istotną treść dokumentu z Chieti został zaczerpnięty z poprzedniego dokumentu, który został przyjęty w Rawennie w 2007 r. Podział ten dotyczy rozumienia prymatu i soborowości na poziomie lokalnym, regionalnym i powszechnym.

\subsection{Synodalność i prymat na poziomie Kościoła lokalnego}

Autorzy dokumentu podkreślają, że powszechność Kościoła wyraża się w Zebraniu eucharystycznym, które przebiega pod przewodnictwem biskupa. To on jest pierwszym (protos) jak też przewodniczącym (proestos) tego Zebrania. Kościół lokalny jest utożsamiany w dzisiejszym życiu empirycznym Kościoła z diecezją (§8). Biskup, który stoi na czele lokalnego Kościoła (diecezji) „czyni widzialną obecność Jezusa Chrystusa (...), liczni wierni i duchowieństwo pod przewodnictwem jednego biskupa łączą się ze sobą w Chrystusie i są we wspólnocie z nim" (§8). W tym kontekście uczestnicy sesji plenarnej w Chieti odnoszą się do eklezjologii św. Ignacego Antiocheńskiego, który w zdecydowany sposób podkreślał relacje Kościoła (lokalnego) ze swoim biskupem ${ }^{10}$. Kościół, który sprawuje Eucharystię pod przewodnictwem swego biskupa stanowi pełnię Kościoła, dlatego, że przebywa w nim Chrystus. Tam gdzie przebywa Chrystus tam jest pełnia Kościoła i ten Kościół (lokalny) staje się Kościołem powszechnym. Innymi słowy każdy Kościół lokalny tj. możemy powiedzieć w dzisiejszym rozumieniu, każda diecezja stanowi pełnię Kościoła, a nie jego część. Na potwierdzenie swych słów członkowie Komisji cytują fragment Listu św. Ignacego Antiocheńskiego do Kościoła w Smyrnie: „Gdzie pojawi się biskup, tam niech będzie wspólnota, tak jak gdzie jest Chrystus, tam i Kościół powszechny (kattholiki ekklesia)" $(8,1)$. Posługa biskupa jest posługą apostolską i wynika z ustanowienia Bożego. W ten sposób biskup jest gwarantem jedności Kościoła i jednocześnie jego głową (§9). Zależność biskupa i jego stada ,jest stałym czynnikiem życia Kościoła lokalnego". Poszczególne lokalne Kościoły nie są rozdzielone pomiędzy sobą. Łączy ich jedna wiara. Natomiast biskup będąc głową swojego lokalne-

\footnotetext{
10 Należałoby dodać, że eklezjologia św. Ignacego Antiocheńskiego legła u podstaw koncepcji ks. Mikołaja Afanasjewa, którą on nazwał eklezjologią eucharystyczną. Współczesna teologia prawosławna w znaczącej mierze czerpie z badań M. Afanasjewa nad św. Ignacym Antiocheńskim (Kozłowski, 1990).
}

go Kościoła jest reprezentantem swojego Kościoła wobec innych wspólnot (§10).

\subsection{Synodalność i prymat na poziomie Kościoła regionalnego}

W naturalny sposób każdy lokalny Kościół tworząc swoją pełnię, nie jest oddzielony od innych wspólnot. Od początku istnienia Kościoła zauważa się pewną współpracę pomiędzy biskupami różnych lokalnych Kościołów. Ta współpraca najbardziej jest widoczna w ustanawianiu nowych biskupów. Dlatego też wymogi kanoniczne zawsze wskazywały, aby w wyświęceniu nowego biskupa uczestniczyło co najmniej dwóch lub trzech biskupów. Współpraca ta zakładała, że któryś z nich pełnił rolę pierwszego (protos), tj. pewnego koordynatora. „Protos, pierwszym spośród biskupów regionu, był biskup pierwszej katedry biskupiej, metropolii, a jego urząd jako metropolity zawsze był związany z jego katedrą biskupią" (§12). Bardzo ważnym czynnikiem w tworzeniu się struktur regionalnych Kościoła, tj. grupowaniu się diecezji w większe skupiska administracyjne Kościoła jest kanon apostolski 34. O ile inne cytowane kanony znajdują swoje odzwierciedlenie w przypisach, o tyle ten kanon jest przywodzony integralnie w treści dokumentu ${ }^{11}$. Omawiany przepis nakazywał aby biskupi danego regionu wybrali spośród siebie pierwszego (protos) i uznawali go za ,głowę (kefale)" i bez jego zgody niczego ważnego nie czynili w danym regionie. Ale też i pierwszy biskup regionu nie może podejmować ważnych decyzji bez konsultacji z innymi biskupami poszczególnych diecezji „ponieważ w ten sposób przetrwa jednomyślność (homonia), a Bóg będzie uwielbiony przez Pana w Duchu Świętym" (§13). Układ, który proponuje kanon apostolski 34 w rzeczywistości sprzyja tworzeniu się ,instytucji metropolii” (§14). Ustanowienie metropolii i powołanie biskupa noszącego miano metropolity, którzy stali na czele Kościołów regionalnych nie zakończyło kształtowania się struktur administracyjnych Kościoła na poziomie regionalnym. Poszczególne metropolie również tworzyły większe okręgi i w ten sposób powstawały patriarchaty. Zasada soborowości jednak w relacjach między patriarchami i pozostałymi biskupami pozostawała nienaruszona. Wszystkie ważne decyzje powinny być podejmowane wspólnie: „Jednakże w sprawach związanych $\mathrm{z}$ ich poszczególnymi metropoliami lub patriarchatami musieli postępować w zgodzie z pozostałymi biskupami. Ten sposób działania znajduje się u podstaw instytucji soborowych w ścisłym tego słowa znaczeniu, takich jak regionalny sobór biskupów" (§14).

Wyrażenia zawarte $\mathrm{w}$ tej części dokumentu z Chieti jak też odwołanie się do kanonu apostolskiego 34, w świadomości prawosławnych jest niezwykle ważnym. Takie rozumienie samodzielności Kościoła regionalnego w świadomości prawosławnej eklezjologii stanowi zasadę funkcjonowania współczesnych Kościołów autokefalicznych,

Kanon apostolski 34 jest też przywodzony w całości w Dokumencie z Rawenny (§24). Taka zależność wskazuje, że jest on bardzo ważny w kontekście kształtowania się struktur kościelnych na poziomie regionalnym. 
gdzie funkcja patriarchy lub metropolity zakłada jego prymat tj. pierwszeństwo w kontekście czci i administracyjnych funkcji. Z drugiej natomiast strony wszystkie ważne decyzje protos $\mathrm{tj}$. patriarcha lub metropolita podejmuje w porozumieniu z pozostałymi (Phidas, 1998, s. 126-130).

Teolodzy rzymskokatoliccy akceptując taki model funkcjonowania i wskazując na jego prawidłowość odszukują odniesienia istniejącego w ich własnym Kościele. Odniesienie to zwykle wskazywane jest na współczesne funkcjonowanie Konferencji episkopatu w danym kraju (Gleaser, 2018, s. 106). Jest to z pewnością właściwe wskazanie niemniej jednak kompetencje Konferencji episkopatu i zakres podejmowania decyzji w jej obrębie jeszcze nie w pełni odzwierciedlają prerogatywy i ducha, który wyrażony jest w kanonie apostolskim 34 .

\subsection{Synodalność i prymat na poziomie Kościoła powszechnego}

Zagadnienie pierwszeństwa na poziomie powszechnym w Kościele jest centralnym punktem dyskusji Kościoła rzymskokatolickiego i prawosławnego. Dlatego też dokument z Chieti poświęca temu zagadnieniu najwięcej miejsca. Temat ten został omówiony w paragrafach 15-19. Autorzy dokumentu kształtowanie się prymatu na poziomie powszechnym odnoszą do okresu pomiędzy IV i VII wiekiem. Wówczas to utworzył się porządek (taxis) pięciu głównych katedr (patriarchów) i został on usankcjonowany przez Sobory powszechne. Pierwsze miejsce wśród tych katedr zajmował Kościół rzymski, po którym następowały katedry Konstantynopola, Aleksandrii, Antiochii i Jerozolimy ${ }^{12}$, zaznaczając przy tym, że „katedra Rzymu zajmowała pierwsze miejsce, sprawując prymat honorowy (presbeia tes times) (§15). Stwierdzenie to odnoszące się do uznania prymatu honorowego a nie jurysdykcyjnego biskupa Rzymu w pierwszym tysiącleciu należałoby określić czymś bardzo ważnym, wręcz przełomowym w kontaktach między Kościołem prawosławnym i rzymskokatolickim. W swojej eklezjologicznej świadomości Kościół prawosławny nigdy nie kwestionował pierwszeństwa katedry rzymskiej pośród innych Kościołów. Natomiast nie przydawał temu pierwszeństwu wartości jurysdykcyjnej. Natomiast eklezjologia Kościoła rzymskokatolickiego dotycząca postrzegania prymatu biskupa Rzymu w pierwszym tysiącleciu nie jednoznacznie wyraża się o jego roli. $\mathrm{Z}$ jednej strony teolodzy zachodni skłonni są twierdzić, że nie sprawował on władzy jurysdykcyjnej nad patriarchatami wschodnimi, z drugiej zaś raczej nie godzą się z mniemaniem, że sprawowanie władzy jurysdykcyjnej w pierwszym Tysiącleciu w Kościele powszechnym przez biskup rzymskiego nie miało miejsca.

Zarówno w postrzeganiu rzymskokatolickim jak i prawosławnym Kościół rzymski cieszył się w pierwszym tysiącleciu szacunkiem pierwszej katedry biskupiej. Źródło tego pierwszeństwa jednak jest odmiennie postrzegane

\footnotetext{
12 Sygnatariusze dokumentu w swoich rozważaniach zsyłają się na następujące kanony Soborów powszechnych: I,6; II,3; IV,28; In Trullo 36.
}

w obu Kościołach. Dokument z Chieti głosi: „Na Zachodzie prymat Stolicy rzymskiej, zwłaszcza od czwartego wieku, był rozumiany w odniesieniu do roli Piotra wśród Apostołów. Prymat biskupa Rzymu pośród biskupów był stopniowo interpretowany jako prerogatywa, która należała do niego, ponieważ był następcą Piotra, pierwszego spośród apostołów. Pojmowanie to nie zostało przyjęte na Wschodzie, gdzie inaczej interpretowano Pismo Święte i Ojców Kościoła w tej kwestii" i dalej w dokumencie stwierdza się: „Nasz dialog może wrócić do tego zagadnienia w przyszłości” (§16). Autorzy dokumentu nie podejmują skomplikowanej dyskusji, której celem byłoby określenie źródła autorytetu lub władzy biskupa rzymskiego. Wskazując na potrzebę zwrócenia się w przyszłości ku temu zagadnieniu można przypuszczać, że jest to temat znacząco skomplikowany i stanowi w pewnym stopniu źródło odmiennego pojmowania.

W dalszej części omawianego dokumentu, uczestnicy sesji w Chieti skupiają się nad zagadnieniem praktykowanej soborowości na poziomie Kościoła powszechnego. Wysyłanie „listów wspólnoty” (communio) było jednym z najważniejszych momentów wzajemnego informowania się poszczególnych patriarchów o wyborze na stanowisko biskupa stolicy. Taka informacja skutkowała wpisaniem imienia nowego biskupa do dyptychu i wymienianiem tego imienia w czasie św. Liturgii. W ten sposób tworzyła się więź eucharystyczna. Natomiast kiedy kilku patriarchów spotykało się i celebrowało wspólnie św. Liturgię, zajmowali oni swoje miejsce zgodnie z porządkiem (taxis) przypisanym przez tradycję kanoniczną ${ }^{13}(§ 17)$.

Najważniejszym jednak momentem soborowości w Kościele jest zwołanie soboru. Pierwsze Tysiąclecie jest okresem pod tym względem wyjątkowym. Wszystkie Sobory powszechne, które uznawane są przez oba Kościoły odbyły się właśnie w tym okresie. Rozważając zależność pomiędzy soborowością i prymatem Kościoła rzymskiego, autorzy dokumentu zwracają uwagę, że biskupi rzymscy osobiście nigdy nie byli obecni na żadnym soborze. Byli natomiast reprezentowani najczęściej przez swoich legatów. Były też przypadki kiedy nawet legaci rzymscy nie uczestniczyli w obradach, ale biskup Rzymu przyjmował jego postanowienia post factum. Współpraca wszystkich biskupów w tym względzie jest bardzo ważna. Natomiast współpraca biskupa Rzymu wydaje się być szczególną ze względu na jego pierwsze miejsce pośród innych biskupów (§18).

W §19 poruszono kolejne zagadnienie związane z szczególną rolą Kościoła rzymskiego - zagadnienie to dotyczy prawa apelacji. Uczestnicy sesji dialogu katolicko -prawosławnego odwołują się do kanonów Soboru lokalnego w Sardyce ${ }^{14}$ wskazując na to starożytne prawo, które

\footnotetext{
13 W dużej mierze opisany porządek odzwierciedla współczesną praktyke stosowana w autokefalicznych Kościołach prawosławnych.

14 Sobór w Sardyce w Prawosławnym Prawie Kanonicznym zaliczany jest do 10 soborów lokalnych, których kanony są obowiązującymi. Przepisy na które zsyłają się uczestnicy Komisji Mieszanej to Kanony 3 i 5 tegoż soboru, gdzie przydawane jest prawo odwołania się do biskupa rzymskiego w przypadku osądzenia biskupa lub innej osoby duchownej przez swój Kościół.
} 
było praktykowane. Jednak prawo apelacji przysługiwało również innym katedrom biskupim, m.in. apelacja mogła być wnoszona do biskupa Konstantynopola. Jednak biskup do którego wnoszono apelację ,jeśli uznał to za właściwe, mógł zarządzić ponowny proces, który winien być prowadzony przez biskupów z prowincji sąsiadującej z prowincją oskarżonego biskupa" (§19). Apelacja, która była wnoszona do biskupa Rzymu przez oskarżonych biskupów ze wschodniej części Kościoła nie oznaczała bynajmniej, że biskupi rzymscy sprawowali władzę kanoniczną nad lokalnymi Kościołami wschodu.

Dokument Komisji Mieszanej Dialogu katolicko-prawosławnego opracowany w Chieti dotykając zagadnienia synodalności i prymatu w pierwszym Tysiącleciu z pewnością jest znaczącym etapem w zbliżeniu Kościołów prawosławnego i rzymskokatolickiego. Zbliżenie to dokonuje się na trwałym fundamencie odszukania wspólnej tradycji łączącej oba Kościoły. Tą wspólna tradycją okazuje się pierwsze tysiąclecie, dlatego też uczestnicy konferencji stwierdzają w przyjętym dokumencie: „To wspólne dziedzictwo zasad teologicznych, postanowień kanonicznych i praktyk liturgicznych z pierwszego tysiąclecia stanowi niezbędny punk odniesienia i potężne źródło inspiracji zarówno dla katolików, jak i dla prawosławnych, kiedy starają się oni leczyć ranę podziału na początku trzeciego tysiąclecia" (\$21). Takie stwierdzenie nawiązujące do odszukania prawdy wiary w okresie kiedy chrześcijanie Kościoła wschodniego i zachodniego stanowili jedno i budowania na tym gruncie jedności zgodne jest $\mathrm{z}$ tym co w teologii prawosławnej zwykło się nazywać „ekumenizmem w czasie". Wyrażenie to wydaje się, że zostało wprowadzone przez ks. Georga Fłorowskiego (Leśniewski, 1995, s. 46) i jak się okazuje w praktyce i życiu współczesnego Kościoła nabiera coraz bardziej realnego znaczenia i właściwej wartości.

\section{Synodalność i prymat w pierwszym Tysiącleciu: Ku wspólnemu rozumieniu w służbie jedności Kościoła ${ }^{15}$}

„Oznajmiamy wam, cośmy ujrzeli i usłyszeli, abyście i wy mieli współuczestnictwo z nami. A mieć z nami współuczestnictwo znaczy: mieć je z Ojcem i Jego Synem Jezusem Chrystusem. Piszemy to w tym celu, aby nasza radość była pełna." (1 J 1,3-4)

1. Wspólnota kościelna wynika bezpośrednio z wcielenia odwiecznego Słowa Boga zgodnie z wolą (eudokija) Ojca przez Ducha Świętego. Chrystus, który przyszedł na ziemię, założył Kościół jako Swoje Ciało (por 1 Kor 12,

SYNODALITY AND PRIMACY DURING THE FIRST MILLENNIUM: TOWARDS A COMMON UNDERSTADING IN SERVICE TO THE UNITY OF THE CHURCH; Joint International Commission for Theological Dialogue between the Roman Catholic Church and Orthodox Church, Chieli, 21 September 2016.
12-27). Jedność, która istnieje między Osobami Trójcy znajduje swoje odzwierciedlenie we wzajemnej wspólnocie (koinonia) członków Kościoła. Tak jak twierdzi św. Maksym Wyznawca, Kościół jest „ikona” Świętej Trójcy. ${ }^{16}$ Na Ostatniej Wieczerzy, Jezus Chrystus modlił się do swego Ojca: ,Zachowaj ich w Twoim imieniu, które Mi dałeś, aby tak jak My stanowili jedno." (J 17,11). Ta trynitarna jedność przejawia się w Świętej Eucharystii, w której Kościół modli się do Boga Ojca przez Jezusa Chrystusa w Duchu Świętym.

2. Od najdawniejszych czasów jeden Kościół istniał jako wiele lokalnych Kościołów. Wspólnota (koinonia) Ducha Świętego (por. 2 Kor 13,13) była doświadczana zarówno w obrębie każdego Kościoła lokalnego, jak i w stosunkach między nimi, jako jedność w różnorodności. Pod kierownictwem tego samego Ducha (J 16,13), Kościół rozwinął schematy porządku i różnych praktyk zgodnie ze swoją naturą jako „lud doprowadzony do jedności poprzez jedność wypływającą z Ojca, Syna i Ducha Świętego" ${ }^{17}$.

3. Synodalność jest fundamentalną cechą Kościoła jako całości. Jak powiedział św. Jan Chryzostom: „Kościót oznacza zarówno zgromadzenie (systema), jak i sobór (synodos)"18. Termin ten pochodzi od słowa sobór (synodos w języku greckim, concilium w języku łacińskim), który oznacza przede wszystkim zgromadzenie biskupów pod przewodnictwem Ducha Świętego, aby wspólnie dyskutować i działań w trosce o Kościół. Ogólnie, odnosi się to do czynnego udziału wszystkich wiernych w życiu i misji Kościoła.

4. Pojęcie prymatu odnosi się do bycia pierwszym (primus, protos). W Kościele prymat należy do jego Głowy Jezusa Chrystusa, „który jest początkiem, pierworodnym spośród umarłych, aby sam zyskał pierwszeństwo (protevon) we wszystkim.” (Kol 1,18). Tradycja chrześcijańska wyraźnie wskazuje, że w życiu soborowym Kościoła na różnych poziomach, biskup był uznawany jako „pierwszy”. Jezus Chrystus wiąże zasadę bycia „pierwszym” z posługą (diakonia): „Jeśli kto chce być pierwszym, niech będzie ostatnim ze wszystkich i sługą wszystkich!” (Mk 9,35).

5. W drugim tysiącleciu wspólnota między Wschodem a Zachodem została zerwana. Wiele wysiłków podjęto by przywrócić wspólnotę między katolikami i prawosławnymi, ale bez powodzenia. Wspólna Międzynarodowa Komisja Dialogu Teologicznego między Kościołem rzymskokatolickim i Kościołem prawosławnym w swojej trwającej pracy, na rzecz przezwyciężenia rozbieżności teologicznych rozważała relacje pomiędzy soborowością a prymatem w życiu Kościoła. Rozbieżne rozumienie tych rzeczywistości odegrało znaczącą rolę w podziale między prawosławnymi i katolikami. Dlatego też koniecznym jest, aby dążyć do wspólnego rozumienia tych komplementarnych rzeczywistości, które się uzupełniają i są nierozłączne.

6. Aby osiągnąc to wspólne rozumienie prymatu i soborowości koniecznym jest, aby zastanowić się nad ich

\footnotetext{
16 Św. Maksym Wyznawca, Mistagogia (PG 91, 663D).

17 Św. Cyprian, O Modlitwie Pańskiej 23 (PL 4, 536).

18 Św. Jan Chryzostom, Explicatio in Ps 149 (PG 55, 493).
} 
historią. Bóg objawia się w historii. Szczególnie ważnym jest, aby wspólnie podejmować teologiczne odczytywanie historii kościelnej liturgii, duchowości, instytucji i kanonów, które zawsze mają wymiar teologiczny.

7. Historia pierwszego tysiąclecia jest w tym przypadku rozstrzygająca. Pomimo pewnych czasowych rozłamów, chrześcijanie ze Wschodu i Zachodu żyli w tym okresie we wspólnocie, i w tym kontekście zostały ustanowione podstawowe struktury Kościoła. Relacje pomiędzy soborowością i prymatem przybrały różne formy, które mogą dać istotne wskazówki dla prawosławnych i dla katolików w ich wysiłkach na rzecz przywrócenia współcześnie pełnej jedności.

\section{Kościół Lokalny}

8. Jeden, święty, powszechny i apostolski Kościół, którego głową jest Chrystus, jest obecny w eucharystycznym zebraniu (synaxis) lokalnego Kościoła pod przewodnictwem swego biskupa. On jest tym, który przewodniczy (proestos). W liturgicznym zebraniu (synaxis) biskup czyni widzialną obecność Jezusa Chrystusa. W Kościele lokalnym (tj. diecezji), liczni wierni i duchowieństwo pod przewodnictwem jednego biskupa łączą się ze sobą w Chrystusie i są we wspólnocie z Nim w każdym aspekcie życia Kościoła, szczególnie w sprawowaniu Eucharystii. Jak nauczał św. Ignacy Antiocheński: „Gdzie pojawi się biskup, tam niech będzie wspólnota, tak jak gdzie jest Jezus Chrystus, tam i Kościół powszechny (katholiki ekklesia)" ${ }^{\prime 19}$. Każdy Kościół lokalny celebruje we wspólnocie z wszystkimi pozostałymi Kościołami lokalnymi, które wyznają prawdziwą wiarę i sprawują tę samą Eucharystię. Kiedy prezbiter przewodniczy Eucharystii, zawsze wspominany jest miejscowy biskup jako znak jedności Kościoła lokalnego. W Eucharystii, proestos i wspólnota są od siebie zależni: wspólnota nie może sprawować Eucharystii bez proestos, a proestos z kolei musi sprawować wraz ze wspólnotą.

9. Ta wzajemna współzależność pomiędzy proestos czy biskupem a wspólnotą jest stałym czynnikiem życia kościoła lokalnego. Wspólnie z duchowieństwem, które jest związane $\mathrm{z}$ jego posługa, lokalny biskup działa pośród wiernych, którzy są stadem Chrystusa, jako gwarant i sługa jedności. Jako następca Apostołów, wypełnia on swoją misję służby i miłości, pasterzując swej wspólnocie i prowadząc ją, jako jej głowa, do coraz głębszej jedności z Chrystusem w prawdzie, zachowując apostolską wiarę poprzez głoszenie Ewangelii i sprawowanie sakramentów.

10. Ponieważ biskup jest głową swojego lokalnego Kościoła, reprezentuje swój Kościół wobec innych lokalnych Kościołów oraz we wspólnocie wszystkich Kościołów. Podobnie urzeczywistnia tę wspólnotę w swym własnym Kościele. Jest to fundamentalna zasada soborowości.

\section{Regionalna wspólnota Kościołów}

11. Istnieją liczne świadectwa, że w starożytnym Kościele biskupi byli świadomi posiadania współodpowiedzialności za Kościół jako całości. Jak powiedział św.

\footnotetext{
9 Św. Ignacy, List do Kościoła w Smyrnie, 8,1
}

Cyprian: ,jest jeden episkopat, na który się składa wielka liczba działających wspólnie biskupów"20. Ta więź jedności została wyrażona w wymogu, by co najmniej trzech biskupów brało udział w święceniach (chirotonia) nowego biskupa; ${ }^{21}$ było to również widoczne $\mathrm{w}$ wielu zgromadzeniach biskupów na soborach lub synodach, gdzie dyskutowano o wspólnych sprawach doktrynalnych i praktycznych (dogma, didaskalia) jak również w częstej wymianie listów i wzajemnych wizytach.

12. Już w pierwszych czterech wiekach pojawiły się różne grupy diecezji w obrębie poszczególnych regionów. Protos, pierwszym spośród biskupów regionu, był biskup pierwszej katedry biskupiej, metropolii, a jego urząd jako metropolity zawsze był związany z jego katedrą biskupią. Sobory Powszechne przypisując pewne prerogatywy (presbeia, pronomia, dikaia) metropolicie, zawsze czyniły to w ramach soborowości. Zatem Pierwszy Sobór Powszechny (Nicea, 325 r.), wymagając od wszystkich biskupów prowincji ich osobistego udziału lub pisemnej zgody na biskupią elekcję i wyświęcenie, akt synodalny - par excellence- nadawał metropolicie uprawomocnienie (kyros) wyboru nowego biskupa ${ }^{22}$. Czwarty Sobór Powszechny (Chalcedon, 451 r.) ponownie przywołał prawa (dikaia) metropolity - podkreślając, że urząd ten ma charakter kościelny, a nie polityczny ${ }^{23}$ - co również uczynił Siódmy Sobór Powszechny (Nicea II, 787 r.) $)^{24}$.

13. Kanon apostolski 34 proponuje kanoniczny opis współzależności między protos a innymi biskupami w każdym regionie: „Biskupi każdego narodu (ethnos) powinni znać pierwszego (protos) wśród nich i uznawać go za głowę (kephale) i nie powinni robić niczego ważnego bez jego zgody (gnome): każdy powinien robić tylko to, co dotyczy jego diecezji (paroikia) i miejsc, do niej należących. Ale i pierwszy (protos) biskup niech nie robi czegokolwiek bez zgody wszystkich. Ponieważ w ten sposób przetrwa jednomyślność (homonoia), a Bóg będzie uwielbiony przez Pana w Duchu Świętym”25.

\footnotetext{
20 św. Cyprian, List 55,24,2; zob. również 'episcopatus unus est cuius a singulis in solidum pars tenetur' (O jedności Kościoła 5 ).

${ }_{21}$ Pierwszy Sobór Powszechny (Nicea, 325), Kanon 4: "Jest rzeczą szczególnie ważną, aby biskup był konsekrowany przez wszystkich biskupów prowincji. Jeśliby to wymaganie napotykało na trudności z powodu pilnej potrzeby, czy gdyby stała na przeszkodzie odległość, niech się zbierze w jednym miejscu przynajmniej trzech biskupów, zaopatrzonych w pisemne zezwolenie nieobecnych, i wówczas dokonają konsekracji. Potwierdzenie (kyros)tego, co się stało, należy w każdej prowincji do biskupa metropolity.” Zob. również Kanon apostolski 1: „Biskup musi być wyświęcony przez dwóch lub trzech biskupów".

22 Pierwszy Sobór Powszechny (Nicea, 325), kanon 4; również kanon 6: "Jeśli ktoś został biskupem bez aprobaty metropolity, wielki sobór zarządził, że nie może on być biskupem."

23 Czwarty Sobór Powszechny (Chalcedon, 451 r.), kanon 12: "Co do miast, które listami cesarskimi otrzymały już tytuł metropolii, to zarówno one, jak i biskup, który nimi zarządza, niech cieszy się jedynie tytułami honorowymi, właściwe zaś uprawnienia zachowujemy dla prawdziwych (kata aletheian) metropolii."

24 Siódmy Sobór Powszechny (Nicea II, 787 r.), kanon 11 ustanawia metropolitom prawo wyznaczania ekonomów w podlegających im diecezjach, jeśli biskupi sami o to nie zadbają.

25 Zob. Sobór w Antiochii (327 r.), kanon 9. „Właściwe jest, by biskup każdej prowincji (eparchia) podlegał biskupowi przewodzącemu metropolii”.
} 
14. Instytucja metropolii jest jedną z form wspólnoty regionalnej między lokalnymi Kościołami. Później wykształciły się inne formy, mianowicie patriarchaty składające się z kilku metropolii. Zarówno metropolita, jak i patriarcha byli biskupami diecezjalnymi z pełną władzą biskupią w swoich diecezjach. Jednakże w sprawach związanych $\mathrm{z}$ ich poszczególnymi metropoliami lub patriarchatami musieli postępować $\mathrm{w}$ zgodzie z pozostałymi biskupami. Ten sposób działania znajduje się u podstaw instytucji soborowych, w ścisłym tego słowa znaczeniu, takich jak regionalny sobór biskupów. Sobory te były zwoływane przez metropolitę lub patriarchę, który im przewodził. On i wszyscy biskupi działali wzajemnie uzupełniając się i będąc odpowiedzialnymi przed soborem.

\section{Kościół na poziomie powszechnym}

15. Pomiędzy IV a VII wiekiem został uznany porządek (taxis) pięciu patriarchalnych katedr, oparty i usankcjonowany przez Sobory Powszechne, z katedrą Rzymu zajmującą pierwsze miejsce, sprawującą prymat honorowy (presbeia tes times), i następujących po niej katedrach Konstantynopola, Aleksandrii, Antiochii i Jerozolimy, w kolejności, zgodnie z tradycją kanoniczną ${ }^{26}$.

16. Na Zachodzie prymat Stolicy rzymskiej, zwłaszcza od czwartego wieku, był rozumiany w odniesieniu do roli Piotra wśród Apostołów. Prymat biskupa Rzymu pośród biskupów był stopniowo interpretowany jako prerogatywa, która należała do niego, ponieważ był następcą Piotra, pierwszego spośród apostołów ${ }^{27}$. Pojmowanie to nie zostało przyjęte na Wschodzie, gdzie inaczej interpretowano Pismo Święte i Ojców Kościoła w tej kwestii. Nasz dialog może wrócić do tego zagadnienia w przyszłości.

17. Kiedy nowy patriarcha był wybierany na jedną z pięciu stolic w taxis, normalną praktyką było to, że wysyłał on list do pozostałych patriarchów, ogłaszając swój

\footnotetext{
26 Zob. I Sobór Powszechny (Nicea, 325 r.), kanon 6: „Starożytny zwyczaj niech będzie zachowywany w Egipcie, Libii i Pentapolis, zgodnie z którym biskup aleksandryjski posiada władzę nad tymi wszystkimi prowincjami, tak jak i biskupowi Rzymu przysługuje podobny zwyczaj. Podobnie ma się rzecz w odniesieniu do Antiochii i innych prowincji: niech będzie zachowane w Kościołach pierwszeństwo (presbeia) wynikająca ze starszeństwa”. II Sobór Powszechny (Konstantynopol, 381 r.), kanon 3: „Biskup Konstantynopola powinien mieć honorowe pierwszeństwo (presbeia tes times) po biskupie Rzymu, ponieważ to miasto jest Nowym Rzymem”. IV Sobór Powszechny (Chalcedon, 451 r.), kanon 28: „Ojcowie słusznie przyznali przywileje stolicy Starego Rzymu, ponieważ był on miastem cesarza. $Z$ tego samego powodu stu pięćdziesięciu najczcigodniejszych biskupów uznało, że najświętsza stolica - Nowy Rzym, zaszczycony pobytem cesarza i senatu i cieszący się takimi samymi przywilejami jak Stary Rzym cesarski, powinien mieć te same przywileje w porządku kościelnym i być na drugim po nim miejscu" (ten kanon nigdy nie był zaakceptowany na Zachodzie). Sobór in Trullo (692 r.), kanon 36: „Odnawiając uchwalenia stu pięćdziesięciu Ojców zgromadzonych w chronionym przez Boga i cesarskim mieście, oraz sześciuset trzydziestu, którzy spotkali się w Chalcedonie, uchwalamy, że siedziba w Konstantynopolu powinna mieć takie same przywileje (presbeia) jak siedziba w Starym Rzymie i powinna być wysoce szanowana w kwestiach kościelnych, jak ta siedziba i ma być druga po niej. Po Konstantynopolu powinna być umieszczona siedziba w Aleksandrii, potem w Antiochii, a potem siedziba w Jerozolimie".

27 Zob. Hieronim, In Isaiam 14, 53; Leon, Sermo 96, 2-3.
}

wybór i załączając wyznanie wiary. Takie „listy wspólnoty" wyrażały głęboko kanoniczną więź jedności wśród patriarchów. Poprzez włączenie imienia nowego patriarchy, w odpowiedniej kolejności, w dyptychach swoich kościołów, czytanych podczas Liturgii, inni patriarchowie uznawali jego wybór. Taxis patriarchalnych katedr miał swój najwyższy wyraz w sprawowaniu świętej Eucharystii. Gdy dwóch lub więcej patriarchów zebrało się, aby sprawować Eucharystię, zajmowali swoje miejsce zgodnie z taxis. Ta praktyka ukazywała eucharystyczny charakter ich wspólnoty.

18. Poczynajac od Pierwszego Soboru Powszechnego (Nicea 325 r.), znaczące kwestie dotyczące wiary i porządku kanonicznego w Kościele były omawiane i rozwiązywane przez Sobory Powszechne. Choć biskup Rzymu nie był osobiście obecny na żadnym z tych soborów, za każdym razem był reprezentowany przez swoich legatów lub zgadzał się z postanowieniami soboru post factum. Kościelne rozumienie kryteriów recepcji soboru jako powszechnego rozwijało się w ciągu pierwszego tysiąclecia. Dla przykładu, pod wpływem okoliczności historycznych, Siódmy Sobór Powszechny (Nicea II, 787 r.) dostarczył szczegółowego opisu kryteriów jakie wówczas były rozumiane: zgoda (symphonia) głów Kościołów, współpraca (synergeia) biskupa Rzymu, oraz zgoda innych patriarchów (symphronountes). Sobór powszechny musi mieć swą własną porządkową liczbę w kolejności Soborów powszechnych, a jego nauczanie musi zgadzać się z nauką poprzednich soborów ${ }^{28}$. Recepcja Kościoła jako całości zawsze pozostawała ostatecznym kryterium powszechności soboru.

19. Na przestrzeni wieków do biskupa Rzymu kierowanych było wiele apelacji, $w$ tym również ze Wschodu, w sprawach dyscyplinarnych, takich jak usunięcie biskupa z urzędu. W czasie Soboru w Sardyce (343) podjęto próbę ustanowienia zasad dla takiej procedury ${ }^{29}$. Sobór w Sardyce zostały przyjęta na Soborze in Trullo (692 r. $)^{30}$. Kanony Soboru w Sardyce ustalały, że biskup który został potępiony mógł wnieść apelację do biskupa Rzymu, a ten, z kolei jeśli uznał to za właściwe, mógł zarządzić ponowny proces, który winien być prowadzony przez biskupów z prowincji sąsiadującej z prowincją oskarżonego biskupa. Apelacje dotyczące spraw dyscyplinarnych były również kierowane do Konstantynopola, ${ }^{31} \mathrm{i}$ do innych stolic biskupich. Takie apelacje do głównych katedr biskupich zawsze były traktowane w sposób soborowy. Apelacje do biskupa Rzymu ze Wschodu wyrażały wspólnotę Kościoła, ale biskup Rzymu nie sprawował kanonicznej władzy nad kościołami Wschodu.

28 Zob. Siódmy Sobór Powszechny (Nicea II, 787 r.): J. D. MANSI, Sacrorum conciliorum nova et amplissima collectio, XIII, 208D-209C

29 Zob. Sobór w Sardyce (343 r.), kanony 3 i 5.

30 Zob. Sobór in Trullo (692 r.), kanon 2. Podobnie Sobór focjańskiw w 861 r. zaakceptował kanony z Sardyki, uznające biskupa Rzymu jako posiadającego prawo kasacji w sprawach już osądzonych przez Konstantynopol

31 Zob. Czwarty Sobór Powszechny (Chalcedon, 451 r.), kanony 9 i 17. 


\section{Konkluzja}

20. W ciągu pierwszego tysiąclecia Kościół na Wschodzie i na Zachodzie był zjednoczony poprzez zachowywanie wiary apostolskiej, utrzymywanie sukcesji apostolskiej biskupów, rozwijanie struktur soborowości, nierozerwalnie złączonych z prymatem i w pojmowaniu władzy jako służby (diakonia) miłości. Choć jedność Wschodu i Zachodu czasami była zakłócana, biskupi Wschodu i Zachodu byli świadomi przynależności do jedynego Kościoła.
21. To wspólne dziedzictwo zasad teologicznych, postanowień kanonicznych i praktyk liturgicznych z pierwszego tysiąclecia stanowi niezbędny punkt odniesienia i potężne źródło inspiracji zarówno dla katolików, jak i dla prawosławnych, kiedy starają się oni leczyć ranę podziału na początku trzeciego tysiąclecia. Na podstawie tego wspólnego dziedzictwa, jedni i drudzy muszą zastanowić się jak prymat, soborowość i wzajemne powiązania między nimi mogą być postrzegane i realizowane dzisiaj i w przyszłości.

\section{Bibliografia}

F. Bouwen, 2010, Belgrad 2006. IXe Session plénière de la Commission mixte international pour le dialogue théologique entre l'Eglise catholique et l'Eglise orthodoxe, „Proche-Oriente-Chrétien", nr 3-4, s. 277-289

F. Bouwen, 2017, Chieti 2016. XIVe Sesion plénière de la Commission Mixte International pour le Dialogue Théologique entre l'Église catholique et l'Église orthodoxe, Proche-Orient Chrétien, 67, s. 97-111.

Bujak Janusz, 2016, Teologiczny dialog katolicko-prawosławny $w$ latach 2005-2015, Szczecin.

Glaeser Zygfryd, 2000, Ku eklezjologii „Kościołów siostrzanych", Opole.

Glaeser Zygfryd, 2018, Teologiczny dialog rzymskokatolicko -prawosławny: stan i perspektywy, [w:] Ekumenizm doktrynalny: schyłek czy nowy początek, red. T. Kałużny, Z. Kijas, Kraków, s. 91-117.

Hryniewicz Wacław, 1993, Kościoły siostrzane, dialog katolicko -prawostawny 1980-1991, Warszawa.

Hryniewicz Wacław, 2004, Kościól jest jeden, Kraków.

Kuźma Andrzej, 2014a, Międzynarodowy dialog teologiczny Kościoła prawosławnego z Kościołem rzymskokatolickim, Elpis 16, s. 11-18.

Kuźma Andrzej, 2005, Spotkanie dotyczace wznowienia dialogu teologicznego z Kościołem rzymskokatolickim, WPAKP 11 (192), s. 11.
Kuźma Andrzej, 2009, Spotkanie prawosławnych i rzymskich katolików na Cyprze, WPAKP 12 (241), s.13.

Kuźma Andrzej, 2010, Kolejne spotkanie prawosławno-katolickie, WPAKP 11 (252), s. 11

Kuźma Andrzej, 2014b, Dialog prawosławno-katolicki, WPAKP 11 (300), s. 8.

Leśniewski Krzysztof, 1995, Ekumenizm w czasie. Prawosławna wizja jedności Kościoła w ujęciu Georges'a Florowskiego, Lublin.

Phidas Vlassios, 1998, Droit canon. Une perspective orthodoxe, Chambésy-Gèneve.

Uniatyzm, metoda unijna przeszłości a obecne poszukiwania petnej wspólnoty tłum pol. W. Hryniewicz, SiDE 1994, 2 (34) s. 77-82.

Konsekwencje eklezjologiczne i kanoniczne sakramentalnej natury Kościoła. Wspólnota kościelna, soborowość i autorytet. Ravenna 13 października 2007, thum. pol. A. Kuźma, WPAKP 2 (219) 2008 cz. I s. 10-13; WPAKP 3 (220) 2008, cz. II s. 11-13

Communique- Jonint International Commission for the Theological Dialogue Between the roman catholic Church and orthodox Church. 14-th Plenary Session, Chieti, Italy, 16-21 september 2016

Rozmiar artykułu: 1,8 arkusza wydawniczego 
ISSN 1508-7719

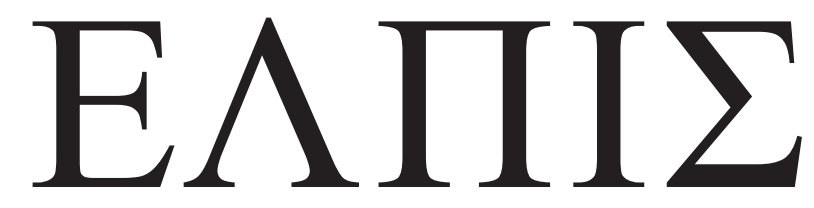

CZASOPISMO TEOLOGICZNE KATEDRY TEOLOGII PRAWOSŁAWNEJ UNIWERSYTETU W BIAŁYMSTOKU

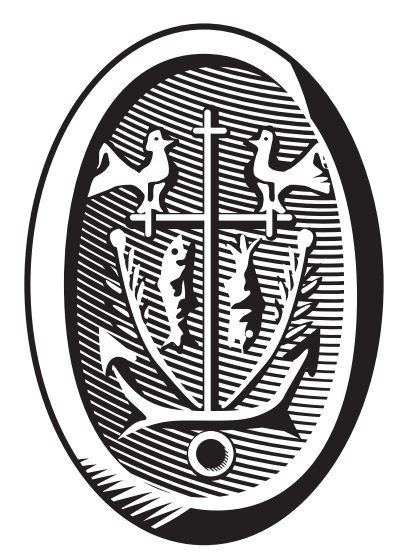

ADRES REDAKCJI

ul. Ludwika Zamenhofa 15, 15-435 Białystok, Polska tel. 85 745-77-80, e-mail: elpis@uwb.edu.pl www.elpis.uwb.edu.pl 